\title{
Pengaruh Kompres Aloe Vera Pada Penderita Dermatitis Di Wilayah Kerja Puskesmas Sumalata Kabupaten Gorontalo Utara
}

\author{
Nanang Roswita Paramata, Nova Afriyani Abas \\ Fakultas Olahraga dan Kesehatan Universitas Negeri Gorontalo \\ Email: roswita@ung.ac.id
}

\begin{abstract}
ABSTRAK
Dermatitis adalah peradangan kulit (epidermis dan dermis) sebagai respon terhadap pengaruh faktor eksogen dan atau faktor endogen, menimbulkan kelainan klinis berupa efloresansi polimorfik (eritema, edema, papul, vesikel, skuama, likenifikasi) dan keluhan gatal. Penelitian ini bertujuan untuk mengetahui pengaruh kompres aloe vera pada penderita dermatitis di Wilayah Kerja Puskesmas Sumalata Kabupaten Gorontalo Utara. Penelitian ini menggunakan jenis penelitian kuantitatif dengan Eksperimen Semu (quasi-expe rimental) menggunakan rancangan penelitiandengan pra-post test design. Populasi sebanyak 25 responden, dengan tehnik pengambilan sampel menggunakan accidental sampling. Sampel penelitian sejumlah 10 responden yaitu penderita penyakit dermatitis. Hasil penelitian ini menunjukkan bahwa setelah diberikan kompres aloe vera kepada 10 responden, semua responden mengalami penurunan gejala. Berdasarkan hasil komputerisasi melalui uji T Berpasangan didapatkan nilai $p$ value $=0,000<\mathrm{a}=0,05$ yang artinya dapat dinyatakan ada pengaruh kompres aloe vera pada Penyakit Dermatitis di Wilayah Kerja Puskesmas Sumalata. Kesimpulan penilitian adalah kompres aloe vera sangat efektif dalam penurunan gejala dermatitis sehingga disarankan kepada penderita dermatitis menggunakan kompres aloe vera untuk menyembuhkan penyakit dermatitis.
\end{abstract}

Kata Kunci : penyakit dermatitis, aloe vera.

\begin{abstract}
Dermatitis is skin inflamation (epidermis and dermis) in response to exogenous and/or endogenous factor, causing clinical abnormalities of polymorphic efflorescence (erythema, edema, papules, vesicles, skuama, lischenification) and itching complaints. This study aims to determine the influence of aloe vera compress in patients with dermatitis in the Work Area of Community Health Center, Puskesmas Sumalata, Gorontalo Utara. Thi quantitative research employed quasi-experimental with pre-posttest design. Further, the research involved 25 respondents as the population by applying accidental sampling technique. The sampleswere 10 respondents of dermatitis patients. Computerization through Paired $\mathrm{T}$ test result reveals $\mathrm{p}$ value $=0.000<\mathrm{a}=0.05$. It is suggested to dermatitis patients to use aloe vera compress to cure dermatitis disease.
\end{abstract}

Keywords: dermatitis disease, aloe vera

\section{Pendahuluan}

Dermatitis atau yang sering disebut eczema adalah peradangan kulit dengan morfologi khas namun penyebabnya bervariasi. Kulit yang mengalami dermatitis memiliki ciri warna kemerahan, bengkak, vesikel kecil berisi cairan, dan pada tahap akut mengeluarkan cairan. Pada tahap kronis, kulit menjadi bersisik, mengalami likenfikasi, menebal, retak, dan dapat berubah warna (Jeyaratnam \& Koh, 2010).

\section{Menurut World Health}

Organization (WHO) tahun (2013) pada survey American Academy of Allergy, Asthma and Immunology (AAAAI), mengungkapkan bahwa dermatitis merupakan masalah kulit yang umum dimana terdapat 5,7 juta kunjungan dokter pertahun akibat penyakit dermatitis. Data Kemenkes RI (2014), bahwa ditemukan jumlah kasus penyakit kulit dan jaringan subkutan lainnya sebesar 15,6\%, dimana penyakit dermatitis sebesar $66,3 \%$. 
Berdasarkan data dari Dinas Kesehatan Provinsi Gorontalo, menunjukan bahwa penyakit dermatitis merupakan urutan ketiga dari 10 penyakit yang menonjol pada tahun 2015-2016. Jumlah kasus dermatitis pada tahun 2015 sebanyak 35.171 kasus, sedangkan pada tahun 2016 sebanyak 26.137 kasus. Kejadian dermatitis di Wilayah Kerja Puskesmas Sumalata Kabupaten Gorontalo Utara, setiap bulannya selalu masuk 10 penyakit terbesar di Wilayah Kerja Puskesmas Sumalata selang tahun 2017. Jumlah kasus dermatitis pada tahun 2017 sebanyak 346 kasus. Dari kasus dermatitis di Wilayah Kerja Puskesmas Sumalata, intervensi yang diberikan yaitu pemberian obat antihistamin dan kortikosteroid untuk mengurangi gejala dermatitis.

Saat ini terdapat penelitian terbaru bahwa lidah buaya dapat menyembuhkan luka, dan dermatitis radiasi.Penelitian yang dilakukan oleh Novyana dan Susanti (2016), mendapatkan hasil bahwa dengan pemberian gel lidah buaya (aloe vera) secara topikal dapat mempercepat proses penyembuhan luka karena tumbuhan lidah buaya dapat merangsang proliferasi beberapa jenis sel.

Penelitian lainnya dilakukan oleh Sharma (2015), dengan judul "Studi Acak Untuk menilai efektivitas Gel Lidah Buaya Pada Dermatitis Radiasi Akut" bahwa aloe vera efektif dalam menunda dan mengurangi tingkat keparahan dermatitis radiasi selama menjalan radioterapi. Beberapa penelitian diatas menemukan bahwa aloe vera dapat mempercepat proses penyembuhan dermatitis, namun belum ada penelitian yang melihat apakah aloe verA (lidah buaya) dapat menyembuhkan dermatitis jenis lainnya.

\section{METODE}

Penelitian ini menggunakan Jenis penelitian kuantitatif dengan Eksperimen Semu (quasi-experimen tal) menggunakan rancangan pene litiandengan pra-post test design. Populasi sebanyak 25 orang, dengan tehnik pengambilan sampel menggunakan accidental sampling. Sampel penelitian sejumlah 10 orang yaitu penderita penyakit dermatitis.

\section{HASIL}

Tabel 1. Gejala dermatitis responden sebelum dan sesudah kompres aloe vera

\begin{tabular}{|c|c|c|c|}
\hline $\begin{array}{c}\text { No. } \\
\text { Responden }\end{array}$ & $\begin{array}{c}\text { Gejala yang timbul } \\
\text { sebelum kompres aloe } \\
\text { vera }\end{array}$ & $\begin{array}{c}\text { Gejala yang timbul } \\
\text { sesudah kompres aloe } \\
\text { vera }\end{array}$ & Keterangan \\
\hline 1 & 3 & 0 & Ada penurunan \\
\hline 2 & 4 & 3 & Ada penurunan \\
\hline 3 & 4 & 2 & Ada penurunan \\
\hline 4 & 6 & 4 & Ada penurunan \\
\hline 5 & 3 & 1 & Ada penurunan \\
\hline 6 & 5 & 2 & Ada penurunan \\
\hline 7 & 4 & 1 & Ada penurunan \\
\hline 8 & 4 & 1 & Ada penurunan \\
\hline 9 & 3 & 1 & Ada penurunan \\
\hline 10 & 6 & 4 & \\
\hline
\end{tabular}


Tabel 2. Pengaruh kompress aloe vera pada penderita dermatitis di wilayah kerja puskesmas Sumalata Gorontalo Utara

\begin{tabular}{clllll}
\hline & Mean & $\mathrm{N}$ & Std. Deviation & Std. Error Mean & Sig. (2-tailed) \\
\hline Pair 1 Pre & 4.20 & 10 & 1.135 & .359 & 0.000 \\
Post & 1.90 & 10 & 1.370 & .433 & \\
\hline
\end{tabular}

\section{PEMBAHASAN}

\section{Identifikasi Gejala Dermatitis Sebelum Diberikan Terapi Kompres Aloe Vera}

Gejala yang dirasakan oleh responden bervariasi yaitu gejala eritema, edema, erosi, gatal, krusta,likenfikasi, vesikel/bula, papul,skuama, dan hiperpigmentasi. Sebelum diberikan kompres aloe vera gejala eritema dialami 7 responden, edema 2 responden, erosi 7 responden, gatal 10 responden, krusta 0 responden, likenfikasi 4 responden, vesikel/bula 1 responden, papul 3 responden, skuama 3 responden, dan hiperpigmentasi 5 responden. Hal ini disebabkan karena terjadi inflamasi pada kulit responden. Berdasarkan teori Djuanda (2007), Dermatitis adalah peradangan kulit (epidermis dan dermis) sebagai respon terhadap pengaruh faktor eksogen dan atau faktor endogen, menimbulkan kelainan klinis berupa efloresansi polimorfik (eritema, edema, papul, vesikel, skuama, likenifikasi) dan keluhan gatal. Tanda polimorfik tidak timbul bersamaan, bahkan mungkin hanya beberapa (oligomorfik). Dermatitis cenderung residif dan menjadi kronis.

Dari 10 responden ada 2 responden memiliki 6 gejala yaitu responden 4 dan 10, hal ini disebabkan karena responden 4 dan 10 menderita dermatitis sudah cukup lama, karena responden melakukan pengobatan di Puskesmas tidak secara rutin sedangkan 3 responden yaitu responden 1, 5 dan 9 yang memiliki gejala yang sedikit yaitu 3 gejala, hal ini disebabkan karena 3 responden baru mengalami penyakit dermatitis sehingga gejala yang timbul hanya 3 gejala.
Dari hasil wawancara yang didapat dari responden penyebab dermatitis pada penelitian tersebut dikarenakan alergi terhadap makanan dan minuman, penggunaan kosmetik, serta diakibatkan oleh penggunaan sabun deterjen. Menurut Suryani, Martini, Susanto (2017), timbulnya penyakit dermatitis diakibatkan oleh dua faktor, yaitu faktor endogen dan faktor eksogen. Faktor endogen meliputi genetik, jenis kelamin, umur, tipe kulit, riwayat alergi dan dan riwayat penyakit kulit. Faktor eksogen meliputi karakteristik paparan bahan iritan, faktor lingkungan, faktor perilaku, faktor mekanik yang berupa tekanan dan gesekan, serta faktor radiasi ultraviolet.

Dari data yang didapat 10 responden yang menderita dermatitis didominasi karakteristik umur yang memiliki jumlah terbanyak adalah pada umur 36-45 tahun sebanyak 4 responden $(40 \%)$. Dan untuk jenis kelamin, yang memiliki jumlah terbanyak adalah perempuan berjumlah 7 responden $(70 \%)$. Menurut Trihapsoro (2003), bahwa dermatitis lebih sering terjadi pada usia dewasa tapi dapat juga mengenai segala usia. Hal ini dimungkinkan karena secara normal semakin bertambahnya umur seseorang maka semakin rendah kemampuan imun atau kekebalan tubuh manusia terhadap serangan atau paparan dari luar tubuh. Pada usia 30 tahun sel kulit lebih sulit menjaga kelembabannya karena menipisnya lapisan basal selain produksi serebum juga menurun tajam, sehingga banyak sel mati yang menumpuk karena pergantian sel (Arman, 2017).

Pada penelitian ini juga kulit wanita lebih rentan terkena dermatitis dibandingkan laki-laki hal ini didukung 
pada tabel 4.1 jumlah responden yang menderita dermatitis didominasi oleh jenis kelamin perempuan sebanyak 7 responden (70\%) dibanding dengan jenis kelamin laki-laki berjumlah 3 responden $(30 \%)$. Berdasarkan Aesthetic Surgery Journal terdapat perbedaan antara kulit pria dan wanita, perbedaan tersebut terlihat dari folikel rambut, kelenjar sebaceous atau kelenjar keringat dan hormon. Kulit pria mempunyai hormon yang dominan yaitu androgen yang dapat menyebabkan kulit pria lebih banyak berkeringat dan ditumbuhi lebih banyak bulu, sedangkan kulit wanita lebih tipis dari pada kulit pria sehingga lebih rentan terhadap kerusakan kulit (Irvan Ade Indrawan, 2014).

\section{Identifikasi Gejala Dermatitis Sesudah Diberikan Terapi Kompres Aloe Vera.}

Setelah diberikan kompres aloe vera terjadi penurunan gejala yaitu pada gejala eritema, edema, erosi, gatal, likenfikasi, vesikel/bula, papul, skuama, dan hiperpigmentasi. dimana dari 7 responden dengan gejala eritema turun menjadi 3 responden, edema dari 2 responden turun menjadi 0 responden, erosi dari 7 responden turun menjadi 4 responden, gatal dari 10 responden turun menjadi 4 responden, likenfikasi dari 4 responden turun menjadi 2 responden, vesikel/bula dari 1 responden turun menjadi 0 responden, papul dari 3 responden turun menjadi 0 reponden, skuama dari 3 responden turun menjadi 2 responden, dan hiperpigmentasi dari 5 responden turun menjadi 4 responden.

Penurunan gejala pada responden ini disebabkan karena intervensi yang diberikan, intervensi tersebut berupa kompres aloe vera yang dilakukan 2 kali sehari pagi dan malam selama tiga hari berturut-turut. Penelitian ini didukung oleh Penelitian yang dilakukan oleh Jisa George T dan K Sharma (2015), bahwa aloe vera berpengaruh pada penderita dermatitis dengan judul studi acak untuk menilai efektivitas gel lidah buaya pada dermtitis radiasi akut, kesimpulan dalam penelitian ini bahwa gel aloe vera efektif dalam menunda dan mengurangi tingkat keparahan dermatitis radiasi selama menjalani radioterapi.

Dalam penelitian ini responden 1 mengalami penurunan gejala yang sangat signifikan yaitu dari 3 gejala yang dialami turun menjadi 0 gejala, hal ini dikarenakan responden 1 sangat responsif dibandingkan dengan responden lainnya dalam melakukan saran yang disampaikan yaitu memperhatikan Personal Hygiene. Menurut Potter (2005), mengatakan bahwa Kebersihan perorangan adalah cara perawatan diri untuk memelihara kesehatan mereka. Kebersihan perorangan sangat penting untuk diperhatikan. Pemeliharaan kebersihan perorangan di perlukan untuk kenyamanan individu, keamanan dan kesehatan (Heviana, 2018).

Penelitian yang dilakukan oleh Novyana dan Susanti (2016), mendapatkan hasil bahwa dengan pemberian gel lidah buaya (aloe vera) secara topikal dapat mempercepat proses penyembuhan luka karena tumbuhan lidah buaya dapat merangsang proliferasi beberapa jenis sel.

\section{Analisis pengaruh kompres aloe vera pada penderita dermatitis di Wilayah Kerja Puskesmas Sumalata.}

Berdasarkan analisa data menggunakan uji Statistik t paired test $p$ value maka didapatkan nilai signifikansi $p$ value 0,000 sehingga $p$ value $<a(0,05)$ Dengan demikian dapat dinyatakan ada pengaruh Kompres Aloe Vera pada Penyakit Dermatitis di Wilayah Kerja Puskesmas Sumalata. Hal ini disebabkan karena adanya pengaruh kompres aloe vera untuk menurunkan gejala dermatitis pada penderita dermatitis. lidah buaya selain digunakan sebagai tanaman penyubur rambut, juga merupakan tanaman obat atau terapi herbal yang 
memiliki efek farmakologi yaitu sebagai anti inflamasi, anti jamur, anti bakteri sehingga berkhasiat dalam mengurangi gejala yang timbul pada penderita dermatitis. Dalam penelitian ini jenis lidah buaya yang digunakan yaitu sudah dalam bentuk produk yang memiliki kosentrasi $92 \%$.

Perbedaan gejala yang turun setelah diberikan kompres aloe vera pada setiap responden dikarenakan karakteristik masing-masing responden yang berbedabeda, dalam penelitian ini Karakteristik jenis kelamin berpengaruh dalam membantu penurunan gejala setelah diberikan kompres aloe vera dimana jenis kelamin perempuan adalah responden yang mengalami penurunan gejala yaitu turun 3 dan 2 gejala sedangkan jenis kelamin laki - laki mengalami penurunan 2 dan 1 gejala. Hal ini di dukung oleh penelitian (Yusuf, 2009), yang mengungkapkan bahwa perempuan mempunyai hormone estrogen lebih banyak dibanding laki - laki, selain itu hormone seks juga dapat mempengaruhi system kekebalan tubuh perempuan. Hormon esterogen dapat mempengaruhi sirkulasi darah pada jaringan, mempertahankan struktur normal jaringan kulit agar tetap lentur, menjaga kolagen kulit agar terpelihara dan mampu menahan air sehingga dapat membantu proses penyembuhan luka.

Menurut Djuanda (2007) ada beberapa hal yang bisa dilakukan untuk membantu mengatasi dan mengendalikan dermatitis yaitu 1.Sistemik : Pada kasus ringan dapat diberikan antihistamin. Pada kasus akut dan berat dapat diberikan kortikosteroid. 2. Topical : Dermatitis akut/basah (madidans) diobati secara basah (kompres terbuka), bila subakut, diberi losion (bedak kocok), krim, pasta, atau linimentum (pasta pendingin). Krim diberikan pada daerah yang berambut. Bila kronik diberi salep. Makin berat atau akut penyakitnya, makin rendah persentase obat spesifik. (Djuanda, 2007). Lidah buaya digunakan untuk mengobati dermatitis kronis dan berat (Saple, 2008). Dalam lidah buaya terdapat Lupeol, merupakan kimia yang paling aktif mengurangi peradangan dalam dosis tertentu dan sterol juga dapat berkontribusi terhadap anti-inflamasi. Lidah buaya mengandung sterol termasuk campesterol, $\beta$-sitosterol, dan kolesterol yang dapat mengurangi inflamasi, membantu dalam mengurangi peradangan rasa sakit dan bertindak sebagai analgesik alami (Singh, 2008).

Tanaman lidah buaya terdiri dari turunan hidroksil antrasena termasuk aloin A dan B2 dengan jumlah 25 sampai $40 \%$ dari senyawa chromone dan turunanya seperti resin aloe A, B2, dan C. Senyawa penting lainnya pada tanaman lidah buaya meliputi beberapa gula seperti glukosa, manosa, dan selulosaberbagai enzim seperti oksidase, amilase, dan katalase dan juga vitamin yang terdiri dari B1, B2, B6, $\mathrm{C}$, E, asam folat, dan mineral seperti kalsium, natrium, magnesium, seng, tembaga, dan krom (Surjushe 2008, dalam Novyana dan Susianti 2016). Lendir lidah buaya mencakup beberapa senyawa seperti vitamin $\mathrm{E}$ dan Vitamin $\mathrm{C}$, dan beberapa asam amino, yang dapat memainkan peran penting dalam percepatan penyembuhan luka sedemikian rupa bahwa percobaan telah menunjukan bahwa vitamin $\mathrm{C}$ dapat berperan dalam peningkatan produksi kolagen dan pencegahan dari sintesis untaian DNA, serta vitmin E sebagai anti oksidan yang kuat dalam penyembuhan luka. Lendir lidah buaya memiliki sistem enzimatik anti oksidan seperti glutathione peroxidase dan superoksida dismutase,yang mempercepat penyembuhan luka dengan netralisasi efek dari radikal bebas yang dihasilkan disitus luka dan dengan properti antiinflamas (Seyyed 2015, dalam Novyana dan Susianti 2016). 
Merujuk kepada beberapa aktifitas farmakologi, dikaitkan dengan tanaman lidah buaya termasuk antiinflamasi, antiarthritis, antibakteri, antijamur, hipoglikemik karena sifat anti bakteri dan anti jamur dari lidah buaya, tanaman ini mencegah terhadap timbulnya ketombe dikepala (Rosca - Casian 2007, dalam Novyana dan Susianti 2016). Penelitian yang dilakukan oleh Haddad, Hashemi, Samsami, Chinichian, Oghabian (2013), yang melakukan penelitian tentang Lidah Buaya untuk Pencegahan Dermatitis Radiasi. Percobaan Klinis Mengendalikan Diri, penelitian ini menyimpulkan bahwa penggunaan profilaksis Lidah buaya mengurangi intensitas dermatitis radiasi. Adapun perbedaan dengan penelitian ini adalah penelitian ini bertujuan meneliti pada pasien yang menjalani radioterapi dengan bidang pengobatan yang lebih besar dan dosis tinggi radiasi.

\section{SIMPULAN}

Setelah diberikan kompres aloe vera terdapat penurunan gejala yang berbeda-beda pada setiap responden yaitu pada gejala eritema, edema, erosi, gatal, likenfikasi, vesikel/bula, papul, skuama, dan hiperpigmentasi.Berdasarkan analisa data menggunakan uji Statistik t paired test $p$ value maka didapatkan nilai signifikansi $p$ value 0,000 sehingga $p$ value $<$ a $(0,05)$. Maka ditolak dan diterima dengan demikian dapat dinyatakan ada pengaruh Kompres Aloe Vera pada Penderita Dermatitis di Wilayah Kerja Puskesmas Sumalata Kabupaten Gorontalo Utara.

\section{DAFTAR PUSTAKA}

Arman, A. U. (2017). Gambaran kejadian dermatitis pada tenaga kerja Indonesia ditempat penampungan sementara di kabupaten nunukan. Kesehatan Masyarakat, 33-42.

Djuanda, P. D. (2007). Ilmu Penyakit Kulit dan Kelamin Edisi

Kelima. Jakarta: Balai Penerbit FKUI.

Heviana, L. N. (2018). Faktor- faktor yang berhubungan dengan kejadian dermatitis kontak pada pekerja pengolahan pabrik karet di provinsi lampung. 1-74.

Irvan Ade Irawan, A. S. (2014). Faktor-Faktor Yang Berhubungan Dengan Kejadian Dermatitis Kontak Iritan Pada Pekerja Bagian Premix di PT. X Cirebon. Jurnal Kesehatan Masyarakat , 110-118.

Jeyaratnam, J., dan Koh, D. (2010). Buku ajar Praktik Kedokteran Kerja. Jakarta: Penerbit

Buku Kedokteran : EGC.

Kemenkes RI., 2014. Profil KesehatanIndonesia Tahun 2014. Jakarta

Kemenkes RI., 2011. Profil KesehatanIndonesia Tahun 2011. Jakarta

Madan, Sharma, Inamdar, Rao dan Singh. (2008). Immunomodulatory Properties of Aloe vera Gel in Mice, International Journal of Green Pharmacy.

Rienda Monica Novyana, S. (2016). Lidah Buaya (Aloe Vera) Untuk Penyembuhan Luka. Majority, 1-5.

Worl Health Organization (2014). Ocupational Contact Dermatitis. Diakses dari www.who.int/gho/data/organisasik esehatandunia.

Yusuf. (2009). Penyembuhan Luka dalam diakses dari http://www.sinagayusuf.com/2009/ 04/19/penyembuhan-luka-ht 